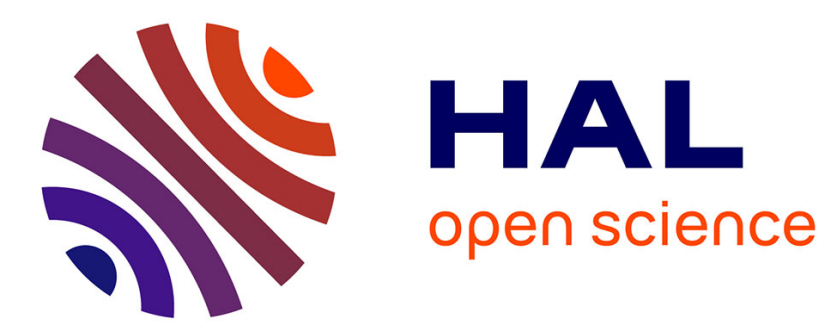

\title{
Handedness and information processing in 2-, 4-, and 6-month-old infants
}

\author{
Hervé Segond, Arlette Streri
}

\section{To cite this version:}

Hervé Segond, Arlette Streri. Handedness and information processing in 2-, 4-, and 6-month-old infants. Infant Behavior and Development, 1996, 19, pp.733. 10.1016/S0163-6383(96)90787-0 . hal03045277

\section{HAL Id: hal-03045277 \\ https://hal.science/hal-03045277}

Submitted on 7 Dec 2020

HAL is a multi-disciplinary open access archive for the deposit and dissemination of scientific research documents, whether they are published or not. The documents may come from teaching and research institutions in France or abroad, or from public or private research centers.
L'archive ouverte pluridisciplinaire HAL, est destinée au dépôt et à la diffusion de documents scientifiques de niveau recherche, publiés ou non, émanant des établissements d'enseignement et de recherche français ou étrangers, des laboratoires publics ou privés. 


\title{
HANDEDNESS AND INFORMATION PROCESSING IN 2-, 4-, AND 6-MONTH-OLD INFANTS
}

\author{
Hervé Segond \& Arlette Streri \\ Laboratoire de Psychologie Différentielle \\ Université René Descartes - Institut de Psychologie \\ 28, rue Serpente - 75006 Paris. France.
}

Motor asymmetries are observed that show a right hand preference for reaching at about 4-5 months old (McCormick \& Maurer, 1980) and a right hand preference for objects holding as soon as two months old (Hawn \& Harris, 1983; Petrie \& Peters, 1980). The study of the development of such manual preferences focuses on infant motor activities and eye-hand coordination. In order to avoid the investigatory limits due to the infant motor immaturity, we examine more precisely the perceptual aspects of haptic exploration in two-, four-, and sixmonth-old infants with a habituation and novelty reaction procedure, that does not involve visual control. We attempt to assess the left- and right-hand performances, as well as the perceptual abilities of both hemispheres by considering information transfer possibilities at these ages.

Procedure :

Ninety-six infants, with an equal number of females and males participated in the experiments. Subjects were divided into test groups : After the habituation phase, half of each age group was tested on either intra-manual discrimination, or on inter-manual recognition. Stimuli were objects that varied according to shape (rectilinear vs curvilinear) and differentiated patterns of holding as well (some of them were narrow and triggered strong grasping, others were bulkier and favoured greater exploration with the fingers).

Results:

- Habituation phase : (1) Tactual habituation was observed for both the right and left hands as early as 2 months. (2) Hoding time at two months old depended on the object's shape (grasping vs handling). (3) The duration of information processing by the left hand became faster between 2 and 4 months old whereas the duration of information processing by the right hand did not evolve.

- Test phase : Within-hand discrimination and between-hand recognition were observed at 2, 4 and 6 months old but only with bulkier objects at 2 months of age. Moreover, right hand discrimination abilities were not found at 6 months, especially for the girls.

\section{Conclusion :}

Lateralization of information processing and hand-use increased as age increased. This lateralization was manifested by the progressive loss of the right hand perceptual function in favour of an object-carrying function, whereas the left hand asserted itself in spatial information processing. The influence of sex appeared at six months of age when girls are more lateralized than boys (greater processing speed with the left hand). 